\title{
Lamprene (Clofazimine) in Leprosy
}

\author{
Basic information. Compiled by \\ S. J. YAWALKAR and W. VISCHER \\ Pharma Division, CIBA-GEIGY Limited, Basle, Switzerland, October 1978
}

We are extremely grateful to CIBA-GEIGY Limited for permission to reproduce in full this 15-page booklet on a drug of increasing interest and value in the treatment of leprosy.

\section{Introduction}

In 1962, Browne and Hogerzeil ${ }^{1}$ first reported on the efficacy of ${ }^{\circledR}$ Lamprene (B $663, \mathrm{G} 30,320$, clofazimine) in leprosy patients in Nigeria. At present, Lamprene is one of the extensively used antileprosy drugs; it is effective in the prevention ${ }^{2-4}$ and treatment of lepra (ENL) reactions ${ }^{5}$ and is also useful for the treatment of dapsone-resistant leprosy cases ${ }^{3,6,7}$. To date, Lamprene is the only major antileprosy drug which displays an anti-inflammatory effect and to which resistant strains of leprosy bacilli have not been reported.

\section{Composition}

The active ingredient in Lamprene is a substituted iminophenazine dye. This bright red dye, the result of progressive molecular manipulation of aniline aposafranine, was synthesized in 1954 by Vincent Barry et al. in Dublin8. Its structural formula and chemical designation are:

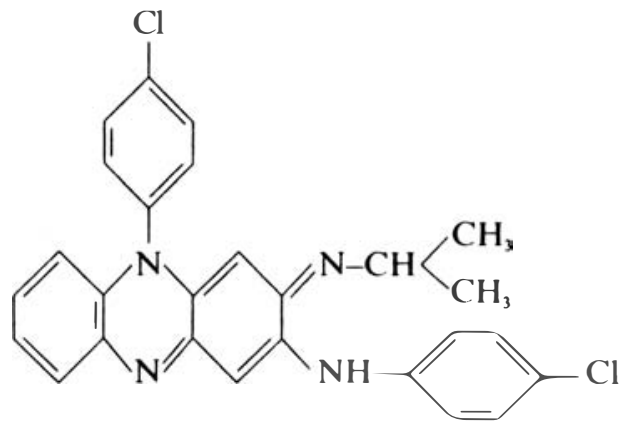

3-(p-Chloro-anilino)-10-(p-chlorophenyl)-2, 10-dihydro-2(isopropylimino)-phenazine (= clofazimine). 


\title{
Presentation
}

Each Lamprene capsule contains $100 \mathrm{mg}$ of micronized clofazimine suspended in an oily base. The product should be protected from humidity and heat. Its shelf-life is 5 years. The capsule shell consists of gelatin, which is known to be sensitive to humidity. Hence, the preparation is supplied in a humidity-resistant container, which should be closed again immediately after use. The capsules may occasionally stick together, but they remain usable.

\section{Absorption, Tissue Distribution and Excretion}

\begin{abstract}
ABSORPTION
Clofazimine absorption varies appreciably from one patient to another. It is more complete from micronized material and from oily preparations. When the active substance is given in the form of coarse crystals, it is absorbed only to the extent of about 20\%, whereas, if taken orally in the form of a microcrystalline suspension in an oil-wax base, an absorption rate of about $70 \%$ has been achieved ${ }^{9}$. This is the reason why Lamprene is supplied in this formulation.
\end{abstract}

\section{SERUM CONCENTRATIONS IN LEPROSY PATIENTS}

In leprosy patients the following serum concentrations have been reported with various dose schedules ${ }^{10}$ :

Oral dose Average serum concentration

$100 \mathrm{mg}$ thrice weekly

$0.5 \mu \mathrm{g} / \mathrm{ml}$

$100 \mathrm{mg}$ daily

$0.7 \mu \mathrm{g} / \mathrm{ml}$

$300 \mathrm{mg}$ daily

$1.0 \mu \mathrm{g} / \mathrm{ml}$

$400 \mathrm{mg}$ daily

$1.4 \mu \mathrm{g} / \mathrm{ml}$

\section{TISSUE DISTRIBUTION}

Lamprene is highly lipophilic and tends to be deposited predominantly in the fatty tissue and in cells of the reticulo-endothelial system. It is taken up by macrophages throughout the body. At autopsies performed on three leprosy patients, clofazimine was found predominantly in mesenteric lymph nodes, adrenals, subcutaneous fat, liver, bile, gall-bladder, spleen, small intestine, muscles, bones, and skin. In these patients, who had received Lamprene in varying dosages of up to $300 \mathrm{mg}$ daily for 35-243 days, the brain concentration was near zero"1. In another autopsy study "ghosts" of clof azimine crystals were observed in histological sections of the intestinal mucosa ${ }^{12}$.

\section{EXCRETION}

The exact manner in which clofazimine is metabolized by the mammalian body is still not completely known. The drug tends to remain a long time in 
human tissues and is eliminated from the body very slowly. Its half-life $\left(t_{1 / 2}\right)$, following oral administration, is at least 70 days in man ${ }^{14}$. Urinary excretion of clofazimine in lepromatous leprosy patients is negligible, accounting on the average for $0.1 \%$ of the dose in $24 \mathrm{~h}$ (range: $0.01-0.43 \%$ ), while faecal excretion varies considerably, amounting in some cases to as much as $35 \%$. Part of the ingested drug recovered from the faeces may represent excretion via the bile rather than failure of absorption from the gut ${ }^{11}$. A small amount is eliminated in the sebum and sweat ${ }^{9}$.

\section{Therapeutic Effect}

Lamprene exerts a potent inhibitory effect on the growth of Mycobacterium leprae (Hansen's bacillus). Its precise mode of action, however, remains to be elucidated. Clofazimine does not show cross-resistance with dapsone or rifampicin.

It is not possible to determine the MIC of clofazimine against leprosy bacilli in animals, since the drug is not very homogeneously distributed in the tissues. Neither blood nor tissue levels necessarily reflect clof azimine concentrations in the immediate environment of Mycobacterium leprae ${ }^{13}$. The determination of the MIC of clof azimine against leprosy bacilli in vitro is not yet feasible.

In the mouse footpad system, the multiplication of Mycobacterium leprae is inhibited by feeding $0.0001 \%-0.001 \%$ clofazimine in the diet ${ }^{15}$. Although bacterial killing begins immediately in lepromatous leprosy patients treated with $50 \mathrm{mg}$ dapsone daily, but only af ter about 50 days in patients receiving 100-200 mg Lamprene daily, the rates of bacterial killing are identical 6 . The reason for the slower onset of action of Lamprent is obscure. Initial killing of leprosy bacilli, monitored by inoculating mice with organisms from skin biopsies taken during the first 24 weeks of treatment, occurs at the same rate whether Lamprene is administered in a dose of $100 \mathrm{mg}$ three times weekly or in one of $200 \mathrm{mg}$ daily on 6 days a week ${ }^{16}$.

Several reports indicate that the overall antibacterial effect of clof azimine in lepromatous leprosy patients is of the same order as that of dapsone ${ }^{17-21}$. In a multicentre double-blind trial carried out in patients with lepromatous leprosy with the aim of comparing the antibacterial effects of low dosages of clofazimine $(100 \mathrm{mg})$ and dapsone $(50 \mathrm{mg})$, both administered twice weekly for 48 weeks, the morphological index (MI) reached zero by the 18 th week in both treatment groups ${ }^{20}$. In previously untreated lepromatous cases, the rate of fall in the MI in response to clofazimine is in general similar to that obtained with dapsone treatment ${ }^{17}$.

Plock and Leiker, however, reported a slightly slower average annual decrease in the bacteriological index (BI) in skin smears and biopsies -- i.e. $13 \%$ and $14 \%$, respectively - in patients receiving clofazimine in dosages of $100-600 \mathrm{mg}$ daily than that reported in patients on sulphone treatment (on the average about $17 \%)^{22}$.

In lepromatous cases clof azimine produces a clinical effect similar to that of dapsone ${ }^{19,23}$. Clinical improvement is visible between the first and third months 
of treatment and is clearly evident by the sixth month. Neuritis and sensory loss also respond well to Lamprene $4,42,44,45$.

Lamprene also displays an anti-inflammatory effect $9,17,24$ which is clinically valuable in controlling erythema nodosum leprosum (ENL) reactions occurring in multibacillary forms of leprosy. It is a drug of choice for the management of ENL in females of child-bearing potential, in whom thalidomide is contra-indicated, and it is a useful means of controlling reversal reactions in borderline leprosy, in which thalidomide is not effective ${ }^{25}$. Lamprene, however, has a slower onset of action than thalidomide and corticosteroids ${ }^{26}$. Although a combination of clof azimine and dapsone does not hasten clinical or bacteriological improvement in patients with lepromatous leprosy, it leads to a considerable reduction in the incidence of ENL reactions ${ }^{5}$ and improves treatment acceptance and patient cooperation.

Combined therapy with clofazimine and dapsone is likely to prevent the emergence of dapsone resistance. Lamprene, given in a dosage of 100-200 mg daily, is effective in proven dapsone-resistant lepromatous leprosy cases ${ }^{3,6,7,26}$. From 1963 to 1968 it was the first alternative for the treatment of dapsoneresistant patients ${ }^{27}$. At present, a combined drug regimen comprising two or three drugs is recommended for such cases.

Although clofazimine is believed to stimulate the phagocytic activity of polymorphonuclear leucocytes and to enhance their oxygen uptake, to date there is no confirmatory evidence of its immunostimulant properties ${ }^{28}$. Moreover, in recent investigations in 5 healthy women it was found to have no effect either on reticulo-endothelial phagocytosis or on the leucocytic index, which suggests that a mechanism of action other than reticulo-endothelial stimulation must be responsible for the therapeutic effect of this drug29.

Lamprene has also been reported to be effective in Buruli skin ulcers caused by Mycobacterium ulcerans ${ }^{30}$.

\section{Indications}

Lamprene is indicated as a part of combined therapy for the prevention or treatment of secondary dapsone resistance in lepromatous and borderline leprosy and for the treatment of erythema nodosum leprosum (ENL) and reversal reactions.

(1) For the prevention of secondary dapsone resistance, Lamprene should be administered to lepromatous (LL) and borderline (BL, BB) leprosy patients in combination with dapsone given in full dosage.

(2) For the treatment of established dapsone resistance, Lamprene should be given in combination with rif ampicin.

(3) Lamprene prevents the occurrence of ENL in reaction-prone lepromatous patients. It can also be used when ENL occurs in patients treated by other drugs and especially in females of child-bearing potential, in whom thalidomide is contra-indicated ${ }^{25}$.

(4) It is also indicated for treating reversal reactions occurring in borderline leprosy, in which thalidomide is not effective, and when corticosteroids are contra-indicated 25,33 . 


\section{Dose Schedules}

It is advisable to administer Lamprene daily or on alternate days ${ }^{15}$. The dosage should be adapted to the individual case, i.e. to the patient's body weight, activity of the disease, and presence of dapsone resistance.

The dose schedules tentatively recommended for adults by the WHO Expert Committee on Leprosy ${ }^{31}$ (1977) are as follows:

(1) Dapsone non-resistant uncomplicated lepromatous (LL) and borderline (BL, BB) leprosy patients (to prevent dapsone resistance and in an attempt to reduce the incidence of ENL reactions):

$100 \mathrm{mg}$ Lamprene orally daily or 3 times a week for the first 4-6 months

$+$

$50-100 \mathrm{mg}$ dapsone orally daily indefinitely.

(2) Established dapsone-resistant cases:

$100 \mathrm{mg}$ Lamprene orally daily indefinitely*

$+$

$600 \mathrm{mg}$ rifampicin orally daily for the first $2-3$ months.

\section{ENL REACTIONS}

The treatment of erythema nodosum leprosum (ENL) depends on the severity of symptoms. ENL is graded severe: if it is accompanied by a high temperature and general malaise; if the skin lesions become pustular and/or ulcerate; if the nerves become painful or if loss of nerve function develops; or if there is evidence of iridocylitis, orchitis, joint swelling, or persistent albuminuria ${ }^{31}$. Severe cases should be referred immediately to hospital, analgesics being given as required for the journey.

In general, the antileprosy treatment should be continued unchanged. The drugs of choice for the treatment of ENL reactions are corticosteroids, thalidomide, and clofazimine. Corticosteroids rapidly control ENL but have to be given continuously and often in increasing dosage, while thalidomide is teratogenic.

In ENL cases, Lamprene should as a rule be given in a dosage of $300 \mathrm{mg}$ daily for about 3 months. The drug has a slow onset of action and therefore takes 4-6 weeks to exert its full effect. In very severe ENL, even at dosages of $300 \mathrm{mg}$ daily (a dose level that should not usually be maintained for longer than about 3 months), clofazimine may not be as effective as corticosteroids or thalidomide ${ }^{31}$. However, unlike corticosteroids and thalidomide, clof azimine not only acts on lepra reactions but also exerts a specific therapeutic effect on leprosy itself. Moreover, its side effects are much less dangerous than those of prednisolone ${ }^{32}$.

\section{REVERSAL REACTIONS}

Prednisolone is an effective form of treatment for reversal (Type 1) reactions, but as these reactions may persist for weeks or months,

\footnotetext{
*Regular clinical and laboratory supervision of these patients is advisable
} 
corticosteroid cover has to be continuous in spite of the risks involved. An alternative drug is clofazimine and the dosage required is usually in the order of $300 \mathrm{mg}$ daily ${ }^{5,33}$.

\section{Toxicity}

Lamprene is a relatively non-toxic drug ${ }^{16}$.

\section{TOXICITY IN ANIMALS}

The acute oral $\mathrm{LD}_{50}$ of clofazimine was found to be $>5 \mathrm{~g} / \mathrm{kg}$ in mice, rats, and guinea-pigs. In the rabbit it was $3.3 \mathrm{~g} / \mathrm{kg}$.

In general, daily oral doses of 30 and $50 \mathrm{mg} / \mathrm{kg}$ given for 6 months were well tolerated by monkeys and rats, respectively. Reddish discoloration of the skin, faeces, and urine was observed. Temporary diarrhoea was occasionally reported in rats ${ }^{34}$.

Clofazimine accumulates selectively in the fat cells and reticulo-endothelial cells of laboratory animals fed with a diet containing the drug. Long-term consequences, if any, of clofazimine crystal deposits in animal tissues are not known. Experimental studies in mice, rats, and rabbits did not yield any evidence that clofazimine possesses a primary embryotoxic or teratogenic action $^{34}$. Clof azimine does not exhibit mutagenic activity ${ }^{38}$.

\section{TOXICITY IN HUMANS}

At autopsies performed on leprosy patients clofazimine has been found in various organs. Histological sections of the intestinal mucosa showed "ghosts" of clofazimine crystals 12 at autopsy of a patient who had received $300 \mathrm{mg}$ clofazimine daily for 6 months and later on a second course of $200 \mathrm{mg}$ a day for $2 \frac{1}{2}$ months after a drug-free interval of 6 months. After 6 and 18 months' regular intake of Lamprene ( $100 \mathrm{mg}$ t.i.d. for the first 3 months followed by a maintenance dose of $100 \mathrm{mg}$ daily), a non-specific granuloma, comprising foreign-body giant cells and lymphocytes together with crystals of clofazimine, was found on laparotomy in the terminal ileum of 2 out of a total of 120 patients in the reactive phase of leprosy. No AFB were grown on culture ${ }^{35}$.

A case of eosinophilic enteritis is reported in a 29 -year-old woman with leprosy who had been receiving clofazimine for 3 years in a dose of $600 \mathrm{mg}$ daily. At laparotomy there was nodular thickening of the upper ileum with blackish-brown pigmentation of the ileal wall. Ileal biopsy revealed the presence of eosinophilic enteritis, and red crystals of clofazimine were observed in unstained sections of the small bowel mucosa and submucosa, as well as in mesenteric lymph nodes ${ }^{36}$. Clofazimine crystals have been found in lymph nodes almost 4 years after treatment with the drug had been discontinued ${ }^{37}$.

A long-term study in 51 patients receiving Lamprene for periods of up to 8 years (comprising 220 patient-years of observation) showed that, despite the deposition of the drug in various tissues in man, Lamprene appears to be remarkably free from serious toxic effects in clinical use. The advantages of 
clofazimine outweigh its known disadvantages in those leprosy patients for whom it is indicated ${ }^{25}$.

Clofazimine crosses the human placenta, since infants born to females who had received the drug during pregnancy were more deeply pigmented at birth ${ }^{17}$. No evidence of teratogenicity has been found 5 .

\section{General Tolerability}

In general, Lamprene is well tolerated and virtually non-toxic. The following side effects have been reported.

\section{SKIN}

Reversible dose-related pink to brownish-black skin discoloration, especially on exposed parts, is the most commonly observed side effect of Lamprene. Discoloration of sweat, hair, sputum, urine, and faeces may occur during clofazimine administration. General dryness of the skin (xeroderma), ichthyosis, pruritus, phototoxicity, acneiform eruptions, and non-specific skin rashes have also been described.

\section{GASTRO-INTESTINAL TRACT}

At present no accurate assessment can be made of the incidence and nature of gastro-intestinal side effects. Symptoms reported include nausea, vomiting, abdominal pain (usually epigastric, but occasionally described as "abdominal cramps" or "colicky"), intermittent loose stools, diarrhoea, anorexia, and weight loss. According to the available literature, there is a possibility of two separate entities:

(1) An early syndrome, commencing within a few days or weeks of starting clof azimine 5 and possibly due to a direct irritant effect of the drug. This syndrome was commoner in response to a high dosage, especially when the drug was given in a single dose, e.g. $300 \mathrm{mg}$ once daily, than when it was administered in divided doses, e.g. $100 \mathrm{mg}$ three times a day. It was possibly more frequent in patients suffering from other concurrent gastro-intestinal diseases, such as amoebiasis and intestinal bacterial infections ${ }^{22}$. The symptoms subsided once the dosage had been reduced or the drug discontinued.

(2) A late syndrome, commencing after some months or years on high dosage (more than $300 \mathrm{mg}$ daily), with persistent diarrhoea, loss of weight, and abdominal pain. This was considered to be the cause of death in one patient who received 100-600 mg clof azimine daily for 6 years because of continued ENL reactions ${ }^{39}$. The syndrome was associated with deposition of clof azimine crystals in the tissues, usually in the submucosa of the small intestine and in the mesenteric lymph nodes $12,37,40,41$. Some of these patients were complex (one had concurrent amyloidosis ${ }^{41}$ and another a tuberculoma of the brain ${ }^{12}$ ). Differing radiological abnormalities and jejunal biopsy findings have been reported, but only a few patients have so far been thoroughly 
studied. No peritoneal fibrosis following clof azimine administration has been observed. In the case of the late syndrome, withdrawal of clofazimine was not necessarily followed by an improvement.

Severe gastro-intestinal side effects are rare; they are likely to occur only following prolonged treatment with the high doses recommended for ENL reactions.

EYE

Except for conjunctival pigmentation ${ }^{5,42}$, interfering neither with the treatment nor with visual acuity, no other ocular side effects have been reported in leprosy patients. However, in 10 out of a total of 26 non-leprosy cases treated with Lamprene in Sweden, reversible linear brownish corneal streaks were observed ${ }^{43}$. These streaks disappeared within 2 months of stopping the drug. In this series 2 cases of macular pigmentation were also noted.

\section{Precautions}

The unwanted reactions to Lamprene are mostly benign, reversible, and of ten dose-related. A dosage of more than $100 \mathrm{mg}$ daily should be given for as short a period as possible ( 3 months) and only under supervision.

The most common side effect is skin discoloration, which can be prevented by reducing the dosage or duration of treatment and by taking protective measures (anti-solar lotions, umbrellas).

As far as possible clof azimine should not be given:

— in the first 3 months of pregnancy

- to patients subject to recurrent abdominal pain and diarrhoea

- to patients with liver or kidney damage.

Lamprene capsules should be taken with meals or with a glass of milk. The dose should be reduced, and if necessary the interval between the doses increased, if the patient complains of colicky or burning pain in the abdomen and/or nausea and vomiting. If diarrhoea or vomiting persists, the patient should be hospitalized.

In patients receiving Lamprene indefinitely for dapsone resistance, or in those with a history of liver or kidney disease, clinical check-ups and laboratory tests, such as routine blood and urine examination, serum bilirubin, serum albumin and globulins, blood urea nitrogen (BUN), and fasting blood sugar, should be carried out at 3-monthly intervals.

\section{References}

1. Browne, S. G. and Hogerzeil, L. M. (1962). B 663 in the treatment of leprosy. Lepr. Rev. 33, 6.

2. Browne, S. G. (1966). B 663 - further observations on its suspected anti-inflammatory action. Lepr. Rev. 37, 141.

3. Azulay, R. D., Da Silva, N. C. and Jesus, M. (1975). Experience with clof azimine in the treatment of leprosy. Le pr. Rev. 46, Suppl.: 99. 
4. Bopp, R., Gervini, R., Bernardi, C. and Kosminski, B. (1972). Lampren en el tratamiento de la hanseniasis. Dermatológica (Mex.) 16, 295.

5. Schulz, E. J. (1972). Forty-four months' experience with clofazimine. Lepr. Rev. $42,178$.

6. Levy, L., Shepard, C. C. and Fasal, P. (1972). Clof azimine therapy of lepromatous leprosy caused by dapsone-resistant Mycobacterium leprae. Amer. J. trop. Med. Hyg. 21, 315.

7. Taylor, P. M., Chacko, C. J. and Job, C. K. (1976). Study of sulphone resistance in leprosy patients in India. Lepr. Rev. 47, 5.

8. Barry, V. C., Belton, J. G., Conalty, M. L., et al. (1957). Rimino-compounds with antituberculosis activity. Nature $\mathbf{1 7 9}, 1013$.

9. Vischer, W. A. (1969). The experimental properties of G 30,320 (B 663). Lepr. Rev. 40, 107.

10. Banerjee, D. K., Ellard, G. A., Gammon, T., et al. (1974). Some observations on the pharmacology of clof azimine. Amer. J. trop. Med. Hyg. 23, 1110.

11. Mansfield, R. E. (1974). Tissue concentrations of clof azimine in man. Amer. J. trop. Med. Hyg. 23, 1116.

12. Desikan, K. V. and Balakrishnan, S. (1976). Tissue levels of clofazimine in a case of leprosy. Lepr. Rev. 47, 107.

13. Shepard, C. C., Ellard, G. A., Levy, L., et al. (1976). Chimothérapie expérimentale de la lèpre. Bull. Org. mond. Santé 54, 235.

14. Levy, L. (1974). Pharmacologic studies of clof azimine. Amer.J.trop. Med. Hyg. 23, 1097.

15. Shepard, C. C. (1969). Minimal effective dosages in mice of clofazimine (B 663) and ethionamide against Mycobacterium leprae. Proc. Soc. Exp. Biol. Med. 132, 120.

16. U.S. Leprosy Panel (U.S.-Japan Cooperative Medical Science Programme) (1976). Spaced clof azimine therapy of lepromatous leprosy. Amer.J. trop. Med.Hyg. 25, 437.

17. Waters, M. F. R. (1969). G 30,320 (B 663), a working party held in London in September 1968. Lepr. Rev. 40, 21.

18. Tolentino, J. G., Rodriquez, J. N. and Abadon, R. M. (1971). Controlled drug trial of B 663 compared with DDS. Int.J.Lepr. 39, 738.

19. Opromolla, D. V. A., Dalpino, D. and Tonello, C. J. S. (1972). Resultados iniciais com clof azimina no tratamento da lepra. An. bras. Derm. 47, 15.

20. Ahrens, T. F., Pettit, J. H. S., Ridley, D. S. and Glaus, L. (1975). Multicentre controlled comparative trial of clofazimine and dapsone in low dosages. Lepr. Rev. 46, 287.

21. Languillon, J. (1975). La clofazimine dans la thérapeutique de la maladie de Hansen. Méd. Afr. noire 22, 825.

22. Plock, H. and Leiker, D. L. (1976). A long-term trial with clofazimine in reactive lepromatous leprosy. Lepr. Rev. 47, 25.

23. Gatti, J. C., Cardama, J. I. and Belina, L. M. (1970). Treatment of leprosy with B 663. Lepr. Rev. 41, 89-92.

24. Karat, A. B. A., Jeevaratnam, A., Karat, S. and Rao, P. S. S. (1970). Double-blind controlled clinical trial of clofazimine in reactive phases of lepromatous leprosy. Brit.med.J. I, 198.

25. Hastings, R. C., Jacobson, R. R. and Trautman, J. R. (1976). Long-term clinical toxicity studies with clof azimine in leprosy. Int. J. Le pr. 44, 287.

26. Languillon, J. (1976). La clof azimine dans la lèpre. Son action sur les formes réactionnelles et les formes résistantes. Méd. trop. 36, 127.

27. Waters, M. F. R. (1977). The diagnosis and management of dapsone-resistant leprosy. Lepr. Rev. 48, 95.

28. Michaelsson, G., Mollin, L. and Oehman, S. (1976). Clofazimine, a new agent for the treatment of pyoderma gangrenosum. Arch. Dermatol. 112, 344.

29. Berghem, L., Lahnborg, G. and Schildt, B. (1977). Does clof azimine affect the macro- and microphage function in man? J. reticuloendoth. Soc. (USA) 21, 171.

30. Oluwasanmi, J. O., Solanke, T. F. and Olurin, E. O. (1975). Mycobacterium ulcerans (Buruli) skin ulceration in Nigeria. Amer. J. trop. Med. Hyg. 25, 122.

31. WHO Expert Committee on Leprosy: Fifth Report, Technical Report Series 607, pp. 21-22 (World Health Organisation, Geneva 1977).

32. Warren, G. (1976). Letter to the editor with comments on the editorial of Leprosy Review on complications of treatment with clof azimine. Le pr. Rev. 47, 344.

33. Jolliffe, D. S. (1977). Leprosy reactional states and their treatment. Brit. J. Dermat. 97, 345. 
34. Stenger, E. G., Aeppli, L., Peheim, E. and Thomann, P. E. (1970). Zur Toxikologie des Leprostaticums 3-( $p$-Chloranilino)-10-( $p$-chlorophenyl)-2, 10-dihydro-2-(isopropylimino)phenazin (G 30,320). Arzneim.-Forsch. (Drug Res.) 20, 794.

35. Karat, A. B. A. (1975). Long-term follow-up of clof azimine in the management of reactive phases of leprosy. Lepr. Rev. 46, Suppl.: 105.

36. Mason, G. H., Ellis-Pegler, R. B. and Arthur, J. F. (1972). Clofazimine and eosinophilic enteritis. Lepr. Rev. 48, 175.

37. Jopling, W. H. (1976). Complications of treatment with clofazimine (Lamprene B 663). Lepr. Rev. 47, 1.

38. Morrison, N. E. and Marley, G. M. (1976). The mode of action of clofazimine. Int. J. Lepr. 44, 133.

39. Harvey, R. F., Harman, R. R. M., Read, A. E., et al. (1977). Abdominal pain and malabsorption due to tissue deposition of clofazimine crystals. Brit. J. Derm. 96, 19.

40. Atkinson, A. J., et al. (1967). Evaluation of B 663 in human leprosy. Int. J. Lepr. 35, 119.

41. Desikan, K. V., et al. (1975). Autopsy findings in a case of lepromatous leprosy treated with clof azimine. Lepr. Rev. 46, 181.

42. Karat, A. B. A. (1973). Clinical trial of Lamprene and dapsone in lepromatous leprosy. 10th Int. Leprosy Congress, Bergen, Abstr., p. 222.

43. Oehman, L. and Wahlberg, I. (1975). Ocular side effects of clof azimine. Lancet II, 933.

44. Pfaltzgraff, R. E. (1972). The control of neuritis in leprosy with clof azimine. Int. J. Lepr. 40, 392.

45. Carayon, A. (1977). La chimiothérapie anti-hansénienne face à la névrite (orientation nouvelle). Hanson. Int. 2, 24. 